\title{
The Internet of politicised 'things': urbanisation, citizenship, and the hacking of New York 'innovation' City
}

\author{
Russell Hughes
}

In 2008 the United Nations predicted that within the year, "for the first time in history the urban population will equal the rural population of the world" (1). As Hodson and Marvin observe, urbanisation "totally dominates the huge metalogistical systems ... that make up the contemporary world" (Hodson and Marvin 2010: 300). Soja and Kanai contend "more than ever before, it can be said that the Earth's entire surface is urbanized to some degree ... no one on Earth is outside the sphere of influence of urban industrial capitalism" (Soja and Kanai 2007: 62). As human population and its urban apparatus proportionately expand, so too do ecological susceptibilities, social ills, and the foment of political unrest. Philosophers Jean Luc Nancy, Henri Lefebvre and Bruno Latour, while critical of the terminal tendencies of techno-capitalist urbanisation, each reimagine the urban as a locus for open-ended 'world forming' resistance. With their theoretical underpinning, this paper undertakes a site-specific analysis of the Applied Sciences New York (ASNY) civic innovation initiative. It argues this new brand of digital urbanism, one designed to be emulated by 'smart cities' the world over, offers abundant opportunities for the kinds of resistance speculatively identified by Nancy, Lefebvre, and Latour.

For Jean Luc Nancy, the central problem with the current urban imaginary is its prioritisation of market over political considerations. In The Creation of the World or Globalization (2007), Nancy identifies urbanisation as the material expression of globalisation, a process that in its "unitotality" (Nancy 2007: 28) signals "an unprecedented geopolitical, economic, and ecological catastrophe" (Nancy 2007: 50). This "indefinite growth of techno-science", which reduces "the circulation of everything" to "the form of commodity" (Nancy 2007: 37), can only result in "correlative exponential growth" and the "worsening of inequalities of all sorts" (Nancy 2007: 33-34). Globalised urbanism not only homogenises sense and flattens meaning (Madden 2012: 776), it "invades and erodes what used to be thought of as globe and which is nothing more now than its double, glomus" (Nancy 2007:33-34), a form of planetary cannibalisation, "an anarchic, polluted dystopia" (Madden 2012: 776) that is "not a nice place" (Madden 2012: 777).

A cursory glance at the evening news on any given day renders Nancy's observations difficult to refute. Yet the proselytisers of the urban millennium do negate such claims, and do so with gusto, espousing the virtue of the new urban condition to be capable of not only solving all the world's urban ills, but making manifest its social utopia idealistically foretold by H.G. Wells more than a century ago (1901). This optimism toward a panaceaic new urbanism will not, however, emerge evenly from a vast undifferentiated global conurban ecumenopolis, but from site-specific urban centres or 'cities' that are ideally positioned to bring urbanism's nascent promise to fruition. For this new urban imaginary, Nancy's glomus is not so much a problem as it is a fortuitous opportunity for commercial solutions, in particular those that navigate cities as dense concentrations of scientific and entrepreneurial 'innovation'. This increasingly prevalent civic story, rising to prominence in the first decades of the $21^{\text {st }}$ century, has its origins in the latter half of the preceding century and is the iterative extension of what was a project to revitalise the first victim of urban sprawl, that being the city itself.

The second coming of the western city

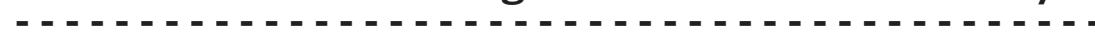

As industrial mass production slumped during the 1960 s and '70s, cities in western developed countries that were home to the factories and workshops of the post-WWII manufacturing boom descended into a period of rapid decline. Vacant buildings, abandoned docklands, and brownfield sites joined forces with mass unemployment to escalate rates of crime, social dissonance, and the ghettoisation of inner city space. Cities became less viable economically and less attractive places to live. Urban planning, which up to that point had concentrated its energies and attentions on regulating and limiting urban growth, beginning in the United States initiated a remarkable about-turn, swiftly reinventing the discipline from being the robust adversary of development to become its complementary collaborator. The buzzword for this renaissance, derived from American rhetorical ingenuity, was 'urban revitalisation'. Re-designating the city's abandoned areas as 'enterprise zones', urban planners used incentives such 
as subsidised land, cheap rents, the reduction of entry and exit fees, and tax exemptions to lure companies that had fled to the suburbs back to their natural domicile. These manoeuvres also catalysed a residential return as the rise of young professionals, frustrated with the mundane banality of sub-urbanism, sought adventure in the dynamism of the metropolis. To attract more people, and keep them there, cities envisaged "entertainment" precincts as a central strategy to treat the inner urban space like a "constantly changing theatre" (Hall 2002: 386).

Perhaps most critical to the success of this urban return was the new economic staple: information and communication technologies (ICTs). In the 1980s and 90s so-called 'new economy', Peter Hall argues "access to privileged information" (Hall 2002: 409) became the key criteria for success. The transfer of this critical currency was, ironically, facilitated by what informational economies were supposed to supplant: face-to-face communication. The recipe for success in the ICT economy, "like all creative activities ... depended on interaction, on networking, on a certain amount of buzz and fizz, which [is] more likely to be found in [cities] than anywhere else" (Hall 2002: 408). This perception highlights not the 'placelessness' of the conurban condition, but the richness of site-specific concentrations of urbanity that cities, in all their idiosyncratic glory, are ideally positioned to provide.

As ICTs faltered in the aftermath of 1998's dotcom crash, the digitisation and commercialisation of biology soon became the best hope for a new era of science-based profitability. Since then, these post-Fordist models of 'flexible' economic accumulation have further broadened the imagination of 'innovation' in its totality by way of a "spiral vortex" (CalIT2 2015) of 'info', 'bio', 'nano', and 'robo' technologies. It is these 'machines' as the engines of urban aspiration that will drive the post-industrial global economy. It follows that what is required of $21^{\text {st }}$ century planning is not so much a concentration of particular industries or technologies per se, rather the spatial and social engineering of 'cultures', 'clusters', 'ecosystems' or 'ecologies' of interconnected innovation industries. Though focusing on the development of exurban science parks in the latter half of the $20^{\text {th }}$ century, and later science precincts within cities in the first decade of the $21^{\text {st }}$, today the city in toto is imagined as the ideal site in which to make innovation manifest as an urban innovation 'laboratory'.

Analogous with, and proportionate to, the ambitions of $21^{\text {st }}$ century science that cities now accommodate, this spatial shift is not only 'best practice' for scientific socialisation and entrepreneurial stimulation, but critically positions the city as the subject of scientific endeavour: that is the problem for 'science' (innovation) to solve. Central to this move is the quantification of activity within cities by corporate giants IBM, Cisco, General Electric and Siemens, who, through the 'smart' mining of civic big data, claim to be able to make cities more productive, liveable, equitable, and resilient. With over half the world's population now living in cities, and the need to accommodate another three billion people in the next 30 years (United Nations 2012: 1), civic administrations across the globe are wholesale investing in the imagined benefits 'smartification' will produce. What becomes apparent, however, is that the mere appearance of 'smart' as semantic veneer is crucial to the task of attracting the global flows of capital and talent upon which $21^{\text {st }}$ century notions of innovation depends. Urban smartification is as much a recruitment strategy designed to draw these critical resources of innovation in advance and independent of anything tangibly innovative or beneficial actually accruing.

$\mathrm{O}_{\mathrm{f}}$ the increasing number of cities retrofitting and rebranding themselves in this regard, the singularly most comprehensive, aggressive, and self- aggrandising ambition for technocratic civic transformation and global innovation domination, is New York City (NYC). Through explication of the origins and organisational elements of NYC's self-appointment as the vanguard of this new global urban imaginary, the following foregrounds how projects such as ASNY agitate and open the potential for new forms of citizen engagement.

\section{Digital urbanism NYC style}

In 2002 NYC's wealthiest citizen, Michael Bloomberg, was elected Mayor on the basis that he could leverage his entrepreneurial talents and industry connections to re-establish the city as an economic world leader. Though he initiated a suite of new policies to achieve this end (Smith 2013: 1), perhaps the most impactful were changes to NYC's public school system. Dogged for decades by mismanagement and corruption, in the six years after taking over the city's public schools, Bloomberg's 'Children First' initiative raised graduation rates by $20 \%$, improved reading and math scores over $10 \%$, and closed the achievement gap between ethnicities (Bloomberg 2008: 1). Bloomberg also initiated a series of new, complementary vocational programs, including opening technology high schools and vocational training centres to serve local technology industries. These policies underpin subsequent changes to the city's tertiary system announced in 2010 that spearhead NYC's bold declaration to transform itself into "the new technology capital of the world" (Cornell Chronicle 2011: 1).

One of Bloomberg's key aims was to diversify the city's economy to reduce its reliance on the financial sector. Under Bloomberg's Mayoralty, NYC's traditional secondary industries such as tourism, film, and television had all grown impressively. When 2007's sub-prime mortgage-lending debacle took effect, the financial industry still accounted for a third of total personal income in the city's private sector. About to lose $\$ 54 \mathrm{~b}$ of market capitalisation and a quarter of its employees in the September 2008 collapse of Lehmann Brothers, Bloomberg overturned the law limiting his Mayoral service to two terms and successfully campaigned as an independent to undertake a third. Part of his re-election platform was flagging the burgeoning technology startup sector in the city as the key industry to drive economic recovery. The success of home-grown tech companies Gilt Groupe, Etsy, Tumblr, and Foursquare, and the organic blossoming of high technology startup districts such as Silicon Alley and Dumbo, signalled NYC was the place in which to merge the worlds of finance, advertising, and media with emergent mobile platforms. City Hall learnt that in order to capitalise on the current tech boom, NYC would need to generate a critical mass of digital engineering talent. Though home to several high-ranking engineering schools, NYC does not produce the volume of engineering graduates that successful innovation districts like Silicon Valley and Boston's Route 128 do, nor does it have the necessary industries and/or associated incentives to keep them after graduation. To this end the Bloomberg administration drafted an audacious plan to not simply make NYC competitive with other booming high-tech centres but to eclipse them. Speaking to this plan at its announcement in December 2010, U.S. Senator Charles E. Schumer declared "look out Silicon Valley, look out Boston, New York will be second to none" (Cornell Chronicle 2011: 1).

One year into Bloomberg's third term as Mayor, the City announced the Applied Sciences New York (ASNY) competition. It requested expressions of interest from academic institutions or joint consortiums to partner with the City to create a state-of-the-art Applied Science Campus (New York City [NYC] 2010: 1). Designed to increase the probability that a high-growth 
company such as Google, Amazon, or Facebook will emerge in NYC (New York City Economic Development Corporation [NYCEDC] 2015: 1), the City offered acreage on a number of prime real estate sites and up to $\$ 100 \mathrm{~m}$ in capital infrastructure expenditure and/or city backed loans as incentive. The campus had to accommodate a minimum of $93,000 \mathrm{~m}^{2}$ of wet and/ or dry labs, provide teaching and conference facilities, and demonstrate a commitment to sustainability and community engagement initiatives with the wider NYC populace. The request stressed the importance of articulating links to corporate partners who would be "co-located" on site. It "strongly" encouraged "proposals that also include space for related commercial activity such as business incubators, corporate research and development facilities, and spin out companies" (NYC 2010: 1).

A little over one year later, Bloomberg announced the joint proposal between Cornell University and Technion Israel Institute of Technology as the winner. Pledging to build a $\$ 2 \mathrm{~b}, 204,000 \mathrm{~m}^{2}$ campus to educate 2,500 postgraduate engineering students annually, the City anticipated Cornell Tech to create "some" 600 spin-off companies and $\$ 23 \mathrm{~b}$ in nominal economic activity within the next 30 years (Cornell Chronicle 2011: 1). Such was the strength of the unsuccessful proposals, that eighteen months later Bloomberg announced a second stage of ASNY; a new Center for Urban Science and Progress (CUSP) to be built in downtown Brooklyn (NYC 2012a: 1). Led by New York University, it partnered with a broader academic consortium, including the City University of New York, Carnegie Mellon University, the University of Toronto, the University of Warwick, and the Indian Institute of Technology Bombay. Two further projects have since been announced: the Columbia Institute for Data Sciences and Engineering (NYC 2012b: 1) within the Morningside Heights and Washington Heights campuses and the Carnegie Mellon/Steiner Studios Digital Media Program (NYC 2013: 1) to be located in the former Brooklyn Navy Yard. Collectively the four ASNY projects are expected to generate over $\$ 33.2 \mathrm{~b}$ in nominal economic activity, more than 48,000 permanent and construction jobs, and approximately 1,000 spin-off companies by 2046 (Cornell Tech 2014:1).

Critical to the urban concerns of this paper is the way in which a Memorandum of Understanding between CUSP, its corporate partners, and the City, establishes the concept of NYC as a 'living laboratory'. With financial and mentoring support from technology companies IBM, Cisco, ConEdison, National Grid, Siemens, Xerox, AECOM, Arup, and IDEO, CUSP and its corporate partners will concentrate on researching and developing technologies that address the critical challenges and emerging growth opportunities in the provision of civic infrastructure, technology integration, energy efficiency, transportation, congestion, public safety, and public health. CUSP has access to NYC's civic data as the raw material by which to isolate [lucrative] targets for research in the aim of developing smart solutions for the growing multitude of aforementioned urban challenges. City Hall's brokering of complementary ventures in the city, such as the partnering of CUSP with the \$20b Hudson Yards 'quantified community' redevelopment (Murray 2014: 1) and the relocation of CUSP partner IBM's third generation cognitive computing program 'Watson' to Manhattan, further buttress CUSP's endeavour to lead the emerging field of 'urban informatics'. With the global market for intelligent city systems and infrastructure estimated to be in the vicinity of $\$ 350$ trillion over the next three decades (World Wildlife Fund 2010: 1), ASNY's state-academyindustry partnership seeks to swiftly 'transfer' R\&D into lucrative products exportable to all other 'urban laboratories' across the globe. By positioning such goods and services as its vehicle for $21^{\text {st }}$ century economic success, the potential ramifications of NYC's aggressive brand of 'digital urbanism' upon the political experience of civic citizens globally, cannot be underestimated.
As Smart Cities author Anthony Townsend points out however, "looking smart, even more than being smart [is] the real force driving mayors into the arms of engineers" (Townsend 2013: 68), "the mere appearance of control ... key to economic survival in a world where cities compete for talent and investment" (Townsend 2013: 71-2). As the move to becoming smarter suggests, cities are increasingly cognisant of, and proactive in, their roles as the powerhouses of the post-industrial new economy. They are also key sites in which new forms of citizenship and political involvement-or the lack thereof-are played out. In its nascent, nebulous 'innovative' imaginary, NYC's digital urbanism concomitantly becomes the focal point for new types of political contestations over individual and collective identity, belonging, and right. If, as Richard Sennett contends, cities need to become more open, enabling citizen participation "by virtue of their own agency" (Sennett 2006: 1), the remainder of this paper will address ASNY's digital urbanism in the context of the citizen circumvention of it, identifying recent incidences of such resistance that gesture toward possible openings for a bottom-up politicised 'world forming' to occur.

\section{The politics of the civic envelope}

As Holsten and Appadurai indicated as early as 1996, with the nation state appearing "increasingly exhausted and discredited", it is cities that "engage most palpably the tumult of citizenship" (Holsten and Appadurai 1996: 188). NYC's quest for innovative civic transformation is especially volatile in this regard, exemplified by Bloomberg's transformative, techno-centric agenda extending from the engineering of the city's major economic industries, to the social engineering of the citizenry of the city itself. NYC's primary, secondary, and now tertiary education reforms seek to equip local students as tools for the $21^{\text {st }}$ century digital economy. They are part of the city's highly manicured posture and projection, which has the intention of attracting the requisite 'mature' techno-entrepreneurial talent to bolster its innovative agenda. These sweeping policy initiatives threaten to disempower and disenfranchise the non-innovative many who currently reside in the city, potentially excluding those who lack the necessary capital and talent required for NYC's aspirational innovation economy.

Just as the new species of technology, in particular the componentry of 'Internet of Things', are designed to seamlessly integrate, skeuomorphlike, into our everyday lives, so too does ASNY's intricately interwoven state-academy-industry 'triple-helix' partnerships. Through the opacity and obfuscation of such complex organisational arrangements, it becomes nearly impossible for citizens to identify, let alone contest, the overarching determinations that govern everyday life. As Adam Greenfield, author of Against the Smart City (2013) contends:

By obscuring the meaningful distinctions between the two [state and market], the 'seamless integration of public and private services' makes it very difficult for any of us to determine which set of actors is able to operate more effectively on our own behalf, which effects we would wish to see sustained and which is more responsive to our demands (Greenfield 2013: 737-40). 
Similarly, artist James Bridle suggests, "Those who cannot perceive the network cannot act effectively within it, and are powerless" (Huffington 2014: 1). Layered in a complex labyrinth of bureaucratic entanglement, the target/s for any kind of citizen-based critique or interrogation have become increasingly difficult to discern. What hope do citizens as selfdetermining subjects have, if the market and its panoply of co-iterative extensions and apparatuses render citizenship purely a matter economic inclusion and exclusion? Given traditional forms of direct resistance and outright revolution appear no longer tenable, what, if any, opportunities are available for citizens to challenge the chimerical conflation of the state and the market, defined by Latour as "two flanks of the same beast" (Latour 2014: 8)?

As David Madden argues, urban economic transformation must concomitantly aspire to political transformation, for without it, "the affirmation of urbanism can easily degrade into cheerleading for conspicuous neighbourhood consumption, 'smart' technocracy, or renewalas-gentrification" (Madden 2012: 783). Instead of promotion of "neo-liberal lifestyle politics", Madden urges a new kind of urban imaginary that privileges citizen-based political potential over the pursuit of economic rationalism at all cost. Though Henri Lefebvre's analysis of the global urban fabric identifies an irreducible remainder and opportunity in what he calls the "non-closing of the circuit" (Lefebvre 1984: 188), Madden contends such a transformation must be "actively sought, rather than only experienced" (Madden 2012: 781). Such speculative opportunities vis-à-vis ASNY will now be ventured.

Michael Bloomberg, a trained engineer, successful entrepreneur, indeed NYC's wealthiest citizen responsible for building the digital products that transformed the city's financial sector, was brought to public office, not so much on a political agenda, but upon his promise to install a model of corporate economic governance. Though it could be said that Bloomberg, like Lefebvre, believes "[u]rban life has yet to begin" (Lefebvre 1996: 150), and furthermore wants a "radical urbanism" that "make[s] a space for audacious, utopian, unrealistic" (Madden 2012: 782) "planning projects" (Lefebvre 1996: 155), these two figures' urban aspirations could not be any more polarised. If, as Madden laments, "the horizon of politics lies in the development of progressively smarter solutions" where "political contentiousness, like pollution, is one more problem to be solved", then, in the context of Bloomberg's 'innovation' city, the task for citizen-based political contestation is to rethink that horizon, and the means by which citizens as a collective arrive at that frontier.

One means toward realising Sennett's anti-teleological 'open city' is via the political philosophy of Bruno Latour. His manifesto for understanding the urban world as one made up of 'things' is particularly useful in this regard. As Latour suggests, "A simple look at them clearly proves that the 'Body Politik' is not only made of people! They are thick with things: clothes, a huge sword, immense castles, large cultivated fields, crowns, ships, cities, and an immensely complex technology of gathering, meeting, cohabiting, enlarging, reducing and focusing” (Latour 2005: 6). Latour sees in 'things' or-to use the old Icelandic word "dings" meaning an assembly of politically charged 'things' (Latour 2005: 12) - an opportunity to revitalise politics via different ways of assembling. As he states, if "those makeshift assemblies we call markets, technologies, science, ecological crises, wars and terrorist networks ... are already connecting people no matter how much they don't feel assembled by any common politics" (Latour 2005: 7), then accordingly once an "assembly of assemblies is deployed, that which passes for the political sphere ... will appear as one type among many others, perhaps even a rather ill-equipped type" (Latour 2005: 24).
At this formative stage, would it appear that the global civic trend toward smart cities is merely a 'smarter' way for triple-helicoid partners to stealthily track and control the flows of their capital and influence? Following Latour's Dingpolitik, could a politicised network of interconnected things serve to disrupt these flows with assemblages that defy the logic of ASNY's transformative civic algorithm? But how, or more importantly what method would a Dingpolitik need to use to do this? Latour suggests, "[w]hat if we had to imagine not an assembly of assemblies, not even an assembly of ways of assembling but an assembly of ways of dissembling? Would not that be a call for disassembling instead?" (Latour 2005: 25). This may seem an anachronistic return to a late $20^{\text {th }}$-century style of Francophilian deconstruction, yet Latour's suggestion could in fact be more prescient than first appearances indicate.

If today's urban condition can be one defined as a "data-industrialacademic-complex" (Woolrich 2014: 1), where, according to Parsons Professor of Urban Ecologies Bill Morrish, "those who control the digital portals in essence control the world" (Morrish personal communications 2014), a myriad of high profile contemporary examples show these portals can be hacked. Just as computer viruses like 'Stuxnet' can be deployed to turn an opposing regime's weapons upon itself, so too have celebrity cyberwhistle-blowers Julian Assange and Edward Snowden used informational platforms to very publicly subvert the foundations of the Nation State. In more modest ways, the destabilisation and diffusion of traditional power strongholds is apparent in a myriad of examples extant in the urban everyday. From eco-philic guerrilla gardeners and environmental health clinics, to the aesthetic interventions of Internet Yami-achi or the jocoserioso of Unfit Bits, disruptive social agitators leverage cyberspace in a multitude of ever-evolving ways to politically impact upon the experience of civic space in three dimensions. As Oli Mould's Urban Subversions and the Creative City (2015) suggests, if today's 'maker' citizens are the benchmark, tomorrow's netizens will be unruly, mutative, politicised in-formations par excellence. ASNY's recruitment of the 'best and the brightest' (Cornell Tech, 2011: 1), is an invitation to the next generation's digital natives to plumb the City's algorithm for technocratic success. ASNY's ambitions, predicated on capturing the precocity of digital wunderkinds to serve the stateacademy-industry triple helix, may well see politically primed students not so much serve their burgeoning intelligence to co-location corporate partners, as supplant them with it. Latour asks, "[p]rogress and succession, revolution and substitution, neither are part of our operating system any longer. And yet where is the alternative OS? Who is busy writing its lines of code?" (Latour 2005: 30). In this context ASNY's intention to harvest the ingenuity of the next generation's most creative thinkers could train what Morrish describes as "the most radically informed radicals on the planet", people who "may not all become quiet Republicans" (Morrish personal communications 2014). ASNY could be unwittingly creating the conditions ripe for a digitised citizen circumvention the likes of which we cannot yet imagine, and Latour's prescience comes to the fore with the suggestion, “when we say 'Public matters!' or 'Back to Things!' we are not trying to go back to the old materialism of Realpolitik, because matter itself [in the new digital imaginary] is up for grabs as well" (Latour 2005: 14). It is precisely in this post-analogue space, where "our usual definitions of politics have not caught up" (Latour 2005: 27), that politics will be most adeptly played by 'infants' speaking in a swiftly evolving silent language or 'code'.

If the most durable forms of innovation, and of politics, are sourced from the "power of the crowd" (Wakefield 2013: 1), the 'smartest' cities will be those that empower the richest ingredient of innovation they have, their citizens, by sponsoring their ability to forge new types of individual and 
collective identity, belonging and right. As Carlo Ratti, head of MIT's Senseable Cities suggests, next generation urban centres will become "more like a shifting flock of birds or shoal of fish, in which individuals respond to subtle social and behavioural cues from their neighbours about which way to move forward" (Wakefield 2013: 1). 'Open' to innovation, as mandated in its operating program, ASNY is not a problem, but a digital opportunity for next generation wunderkinds to playfully, and powerfully, hack out. Viewed in this way, is New York 'innovation' City in its nascent state a potential precursor to a contra philosophy for the $21^{\text {st }}$ century, a wide open "crack for freedom to slip through, silently filling up empty spaces, sliding through the interstices" (Lefebvre, 1995 [1960]: 124)?

Acknowledgements

I acknowledge Professor Sandra Kaji-O'Grady of the University of Queensland, and Professor Bill Morrish of Parsons, for their support in the production of this

article.

Disclosure Statement

No potential conflict of interest is reported by the author. 


\section{References}

Appadurai, A., \& Holston, J. (1996). Cities and citizenship. Public Culture 8, 2, 187-204.

Bloomberg, M. (2008, Thursday January 17). Mayor Bloomberg's 2008 state of the city address. New York Times. Retrieved from http://www.nytimes.com/2008/01/17/nyregion/17stateofnyc.html?pagewanted=all\&_r=\&

CalIT2. (2015). About Us. Retrieved from http://www.calit2.net/about/index.php

Cornell Chronicle. (2011, Monday December 19). Cornell wins NYC tech campus bid. Retrieved from http://www.news.cornell.edu/stories/2011/12/cornell-wins-nyc-tech-campus-bid

Cornell Tech. (2014, Monday November 12). AOL, Cornell Tech \& city officials launch the Connected Experiences Lab. Retrieved from http://tech.cornell.edu/news/aol-cornell-tech-city-officials-launch-the-connected-experiences-lab

Doxiadis, C., \& Papaioannou, J. (1974). Ecumenopolis: The Inevitable City of the Future. New York: W. W. Norton.

Geddes, P. (1949 [1925]). Cities in Evolution. London: Williams and Norgate.

Greenfield, Adam. (2013). Against the Smart City. New York: Verso.

Hudson Yards. (2014, Thursday April 17). About. Retrieved from http://www.hudsonyardsnewyork.com

IBM. (2014, Thursday January 9). IBM forms new Watson group to meet growing demand for cognitive innovations. Retrieved from http://www-03.ibm.com/press/us/en/pressrelease/42867.wss

IBM. (2015). Smarter Cities. Retrieved from http://www.ibm.com/smarterplanet/us/en/smarter_cities/overview/

Hall, P. (2002). Cities of Tomorrow. Oxford: Blackwell.

Huffington, A. (2014, Thursday January 16). Drone Shadow: Design and Violence. Moma. Retrieved from http://designandviolence.moma.org/drone-shadow-james-bridle/

Latour, B. (2005). From Realpolitik to Dingpolitik, or how to make things public. In Making things public - atmospheres of democracy, exhibition catalogue, March-August 2005, ZKM Centre for Art and Media, Karslruhe. Retrieved from http://www.bruno-latour.fr/sites/default/files/downloads/96-MTP-DING.pdf

Latour, B. (2014, Wednesday February 26). On some of the affects of capitalism. Lecture given at the Royal Academy, Copenhagen. Retrieved from http://www.bruno-latour.fr/ sites/default/files/136-AFFECTS-OF-K-COPENHAGUE.pdf

Lefebvre, H. (1984). Everyday Life in the Modern World. New Brunswick, NJ: Transaction.

Lefebvre, H. (1995 [1960]). Introduction to Modernity: Twelve Preludes September 1959-May 1961. New York: Verso.

Lefebvre, H. (1996). Writings on Cities. (E. Kofman, E. Lebas, Trans.). Malden, MA: Blackwell. 
Lefebvre, H. (2003). The Urban Revolution. (R. Bononno, Trans.). Minneapolis, MN \& London, England: University of Minnesota Press.

Madden, D. (2012). City becoming world: Nancy, Lefebvre, and the global-urban imagination. Environment and Planning D: Society and Space, $30,772-787$.

Mould, O. (2015). Urban Subversions and the Creative City. London: Routledge.

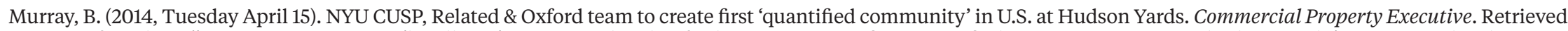
from http://www.cpexecutive.com/headlines/nyu-cusp-related-oxford-team-to-create-first-quantified-community-in-u-s-at-hudson-yards/1004094679.html

Nancy, J.-L. (2007). The Creation of the World or Globalization. Albany, NY: SUNY Press.

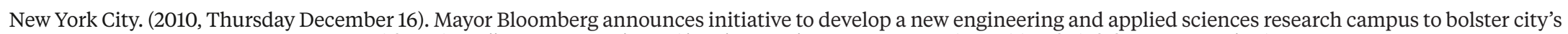
innovation economy. Retrieved from http://www.nyc.gov/portal/site/nycgov/menuitem.c0935b9a57bb4ef3daf2f1c701c789a0/index.jsp?pageID=mayor_press_ release\&catID=1194\&doc_name=http\%3A\%2F\%2Fwww.nyc.gov\%2Fhtml\%2Fom\%2Fhtml\%2F2010b\%2Fpr512-10.html\&cc=unused1978\&rc=1194\&ndi=1

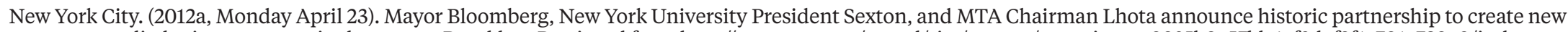
applied sciences center in downtown Brooklyn. Retrieved from http://www.nyc.gov/portal/site/nycgov/menuitem.c0935b9a57bb4ef3daf2f1c701c789a0/index. jsp?pageID=mayor_press_release\&catID=1194\&doc_name=http://www.nyc.gov/html/om/html/2012a/pr147-12.html\&cc=unused1978\&rc=1194\&ndi=1

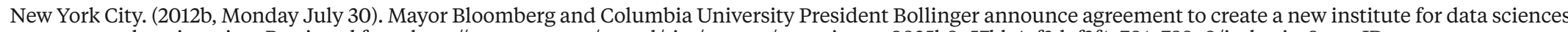
and engineering. Retrieved from http://www.nyc.gov/portal/site/nycgov/menuitem.c0935b9a57bb4ef3daf2f1c701c789a0/index.jsp?pageID=mayor_press_ release\&catID=1194\&doc_name=http\%3A\%2F\%2Fwww.nyc.gov\%2Fhtml\%2Fom\%2Fhtml\%2F2012b\%2Fpr280-12.html\&cc=unused1978\&rc=1194\&ndi=1

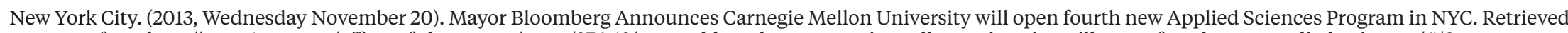
from http://www1.nyc.gov/office-of-the-mayor/news/376-13/mayor-bloomberg-carnegie-mellon-university-will-open-fourth-new-applied-sciences/\#/0

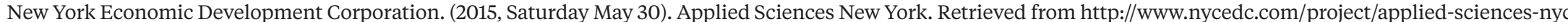
Sennett, R. (2006, November). The open city. Urban Age. Berlin. Retrieved from http://downloads.1secities.net/0_downloads/Berlin_Richard_Sennett_2006-The_ Open_City.pdf

Smith, C. (2013, September 8). Autocrat for the People. New York Magazine. Retrieved from http://nymag.com/news/politics/bloomberg/legacy-2013-9/index1.html

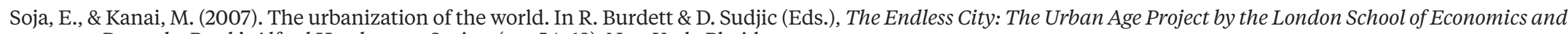
Deutsche Bank's Alfred Herrhausen Society (pp. 54-69). New York: Phaidon.

Townsend, A. (2013). Smart Cities: Big data, Civic hackers, and the Quest for a New Utopia. New York: Norton.

United Nations. (2008, February). World Urbanization Prospects: The 2007 Revision. Department of Economic and Social Affairs, Population Division.

United Nations. (2012, March). World Urbanization Prospects: The 2011 Revision. Department of Economic and Social Affairs, Population Division.

Wakefield, J. (2013, Sunday February 17). How will our future cities look? BBC Technology News. Retrieved from http://www.bbc.com/news/technology-20770518

Wells, H.G. (1901). Anticipations of the Reaction of Mechanical and Scientific Progress upon Human Life and Thought. New York: Harper and Bros.

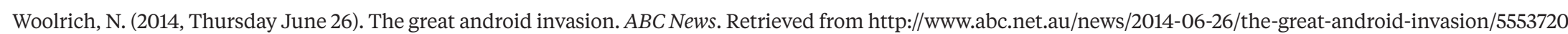

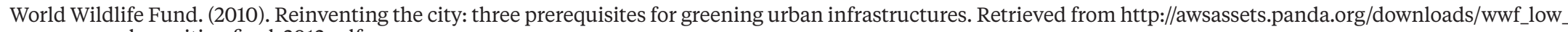
carbon_cities_final_2012.pdf 